\title{
Focal meningoencephalitis and mycotic aneurysms from suspected aneurysm coil seeding
}

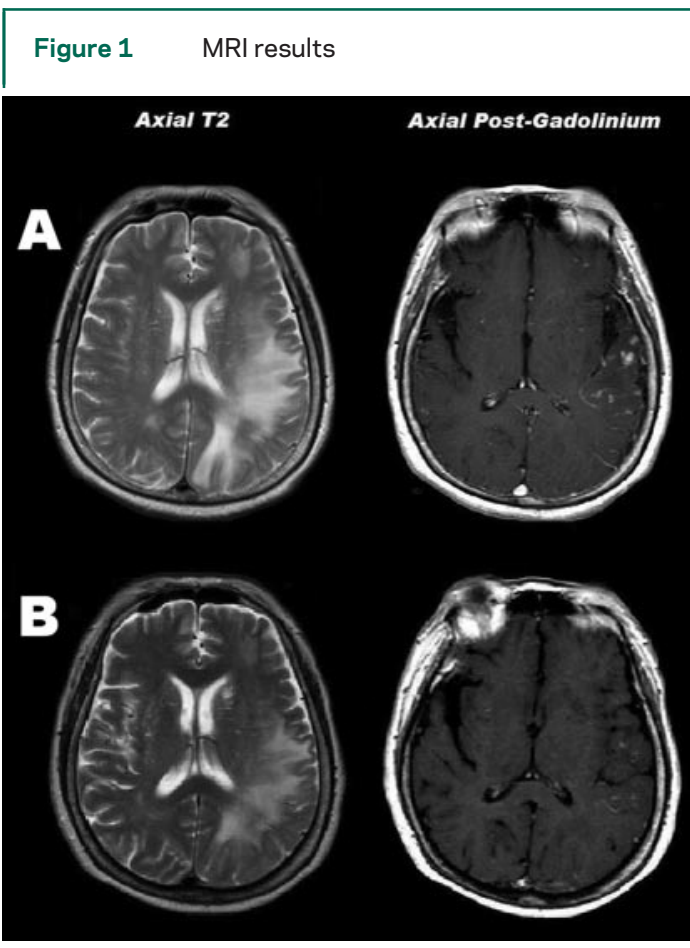

MRI demonstrates vasogenic edema on T2 and multiple nodular foci of enhancement on T1 (A) with improvement after 5 days of therapy (B).

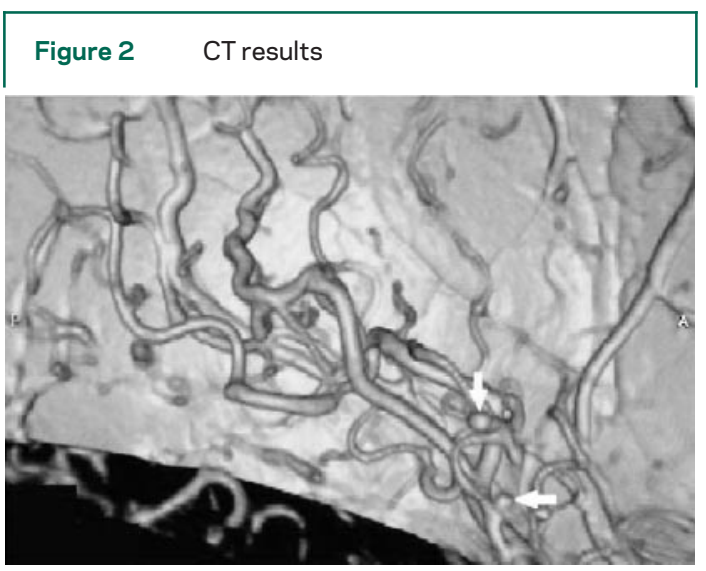

Three-dimensional reconstructed CT angiography shows mycotic aneurysms (arrows) in the left middle cerebral artery.

A 68-year-old woman with a left internal carotid artery aneurysm coiled 3 months previously presented with hemoptysis, fever, aphasia, and right hemiparesis. Imaging demonstrated left hemispheric nodular meningoencephalitis (figure 1A) and mycotic aneurysms (figure 2). Serum white blood cell (WBC) count was $13,000 / \mu \mathrm{L}$. CSF showed 11 WBCs ( $76 \%$ lymphocytes), 109 red blood cells, $67 \mathrm{mg} / \mathrm{dL}$ protein, and $77 \mathrm{mg} / \mathrm{dL}$ glucose, but all other studies were negative.

A single 6-mg dose of decadron was given. Admission medications subsequently discontinued were IV acyclovir $600 \mathrm{mg} \mathrm{q} 8$ hours and amphotericin (ABLC) $300 \mathrm{mg} \mathrm{q} 24$ hours after 4 days and Ceftriaxone $2 \mathrm{~g} \mathrm{q} 12$ hours after several days. Because of hemoptysis, CSF results, and initial response to it, she remained on antituberculosis agents (ethambutol, pyrazinamide, isoniazid, rifampin). She was neurologically normal and afebrile in 72 hours, with improvement in her MRI (figure 1B).

This response supports an infectious etiology. The left carotid distribution makes her coil mass a likely source. Coil seeding can occur, ${ }^{1}$ but seeded intracranial aneurysm coils are rare.

Yince Loh, MD; Paul M. Vespa, MD; Fernando Viñuela, MD, Manhattan Beach, CA Disclosure: The authors report no conflicts of interest.

The views expressed in this article are those of the authors and do not reflect the official policy or position of the Department of the Army, the Department of Defense, or the United States Government.

Address correspondence and reprint requests to Dr. Y. Loh, Division of Interventional Neuroradiology, David Geffen School of Medicine at UCLA, BL-133 CHS, Mail Code 951721, Los Angeles, CA 90095; yloh@mednet.ucla.edu

\section{REFERENCE}

1. Shinkawa T, Yamagishi M, Shuntoh K, Fujiwara K, Watanabe T, Yoshida S. Infectious ductal aneurysm after coil embolization in an infant. Ann Thorac Surg 2006;81:339-341. 


\section{Neurology}

\section{Focal meningoencephalitis and mycotic aneurysms from suspected aneurysm coil seeding}

Yince Loh, Paul M. Vespa and Fernando Viñuela

Neurology 2007;69;613

DOI 10.1212/01.wnl.0000275546.50250.22

This information is current as of August 6, 2007

\section{Updated Information \&} Services

References

Permissions \& Licensing

Reprints including high resolution figures, can be found at: http://n.neurology.org/content/69/6/613.full

This article cites 1 articles, 0 of which you can access for free at: http://n.neurology.org/content/69/6/613.full\#ref-list-1

Information about reproducing this article in parts (figures,tables) or in its entirety can be found online at:

http://www.neurology.org/about/about_the_journal\#permissions

Information about ordering reprints can be found online: http://n.neurology.org/subscribers/advertise

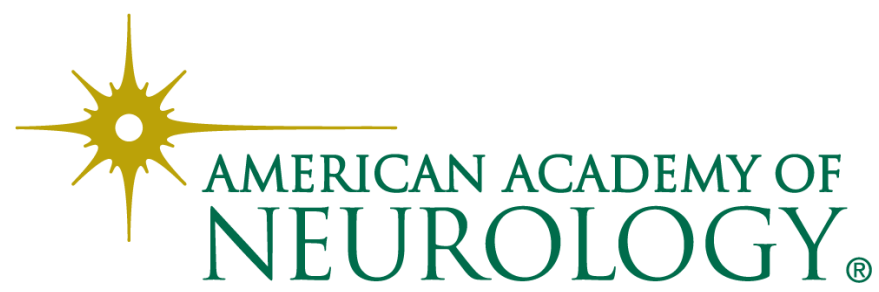

